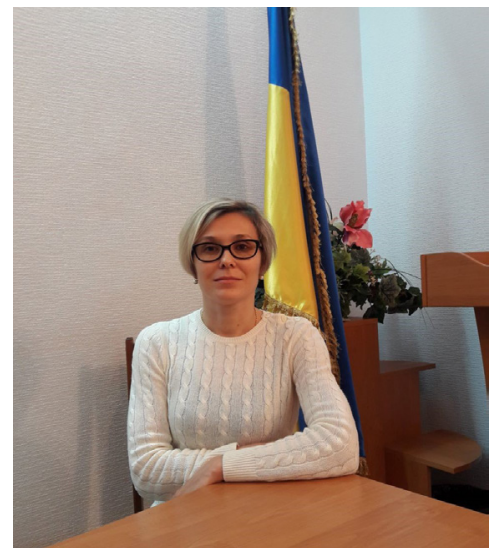

Марія Редькіна,

старший викладач кафедри фізичного

виховання і спорту,

Національний педагогічний університет

імені М.П. Драгоманова

(м. Київ, Україна)

Mariia Redkina,

Senior Lecturer of the Department

of Physical Education and Sports,

National Pedagogical Dragomanov University

(Kiev, Ukraine)

rmadniprowood@gmail.com

ORCID ID 0000-0002-2474-1001

УДК: 37.091.212:37]:796.012.36

\title{
ОСОБЛИВОСТІ ІНДИВІДУАЛЬНОЇ РУХОВОЇ АКТИВНОСТІ СТУДЕНТІВ ПЕДАГОГІЧНИХ СПЕЦІАЛЬНОСТЕЙ
}

Анотація. У зв'язку із постійним науково-технічним розвитком суспільства виникає недостатність рухової активності у студентів закладів вищої освіти, яка у більшості випадків є причиною виникнення різних захворювань.

У статті аналізується проблема організації рухової активності студентів педагогічних спеціальностей. Підкреслено, що рухова активність студентської молоді розглядається як невід'ємна частина життєдіяльності.

Зазначено, що структура рухової активності багатогранна і індивідуалізована для кожної окремої людини. Охарактеризовано, як в умовах розумової зайнятості студенти організовують своє дозвілля.

3'ясовано головні причини, які сприяють розвитку гіподинамії серед студентської молоді. Особливу роль у цій проблемі відіграє організація рухового режиму студентів педагогічних спеціальностей, навчання яких пов'язано з малою руховою активністю. Хронічний дефіцит рухової активності у режимі студентської молоді стає реальною загрозою її здоров'ю та нормальній фізичній працездатності.

Підкреслено, що вирішення піднятої проблеми можливе за рахунок інтенсивного використання всіх засобів фізичної культури.

Підсумовано, що більшість студентів педагогічних спеціальностей веде малорухливий спосіб життя, що впливає на їх психоемоційний і соматичний стан в результаті низької або помірної фізичної підготовки. Впровадження програм фізкультурно-оздоровчих занять, побудованих на стимулюванні мотивації до систематичних занять фізичними вправами, буде сприяти залученню студентів до рухової активності.

Ключові слова: рухова активність, студенти, гіподинамія, здоровий спосіб життя.

\section{PECULIARITIES OF INDIVIDUAL MOBILE ACTIVITY OF STUDENTS OF PEDAGOGICAL SPECIALTIES}

Abstract. Due to the constant scientific and technical development of society, there is a lack of motor activity in students of institutions of higher education, which in most cases is the cause of various diseases.

The article analyzes the problem of organizing motor activity of students of pedagogical specialties. It is emphasized that motor activity of student youth is considered as an integral part of life activity.

It is stated that the structure of motor activity is multifaceted and individualized for each individual. It describes how students organize their leisure activities in terms of mental employment.

The main reasons that contribute to the development of hypodynamia among student youth have been identified. The level of motor activity of students of pedagogical specialties is investigated.

Practical experience shows that students of pedagogical specialties are not able to fully organize their motor activity.

The question of optimal motor regimes, their volumes and intensity has been well studied in relation to the method of training athletes. A special role in this problem is played by the organization of the motor mode of students of pedagogical specialties, the training of which is connected with the low motor activity. Chronic impaired motor activity in the mode of student youth becomes a real threat to her health and normal physical performance.

It is emphasized that the options for solving this problem are possible due to the intensive use of all means of physical culture.

It is summarized that the majority of students of pedagogical specialties lead a sedentary lifestyle that affects the psychoemotional and somatic state of students as a result of low or moderate physical fitness. Implementation of programs of physical and health classes, which are based on stimulation of motivation to systematic physical exercises, will help to attract students to physical activity.

Keywords: motor activity, students, hypodynamia, healthy lifestyle. 


\section{ВСТУП}

Постановка проблеми. Проблема дослідження й оцінки рухової активності досі залишається актуальною, оскільки рухова активність є одним з головних факторів, що визначають здоров'я та рівень фізичного стану населення (Анікєєв Д., 2012, с. 19).

У XXI столітті набули поширення серцево-судинні захворювання, які пов'язані з недостатнім обсягом рухової активності. Захворюваннями минулого століття, хворобами цивілізації терапевти називають атеросклероз, гіпертонічну хворобу, стенокардію та інфаркт міокарда (Куц А., 1993, с. 250). Їхнє поширення у наш час не випадкове - воно безпосередньо пов'язане із зміною рухового режиму більшої частини населення, що зумовлене сучасними умовами життя: швидкими темпами розвитку техніки, ростом інформації, збільшенням нервово-психічного напруження (Ніколаєв С., 2004, с. 20).

Аналіз останніх досліджень і публікацій. У зв'язку з порушенням балансу між споживаною їжею, фізичним навантаженням і відпочинком людини особливої уваги потребує раціональна організація рухової активності (Блавт О., 2012). Особливу роль у цій проблемі відіграє організація рухового режиму студентів педагогічних спеціальностей, навчання яких пов'язано з малою руховою активністю. Хронічний дефіцит рухової активності у режимі студентської молоді стає реальною загрозою ї̈̈ здоров'ю та нормальній фізичній працездатності (Сікура А., 2012). Саме рухова активність перш за все впливає на процеси обміну в організмі людини. Крім того, під час фізичних вправ в організмі спрацьовують певні механізми, в результаті дії яких посилюються функції не тільки м'язів, але й дихальної, серцевосудинної, нервової та травної систем. Завдяки здатності організму до саморегуляції відбувається його адаптація до змін зовнішнього середовища, організм стає стійкішим і життєздатнішим.

Незважаючи на велику кількість праць, присвячених питанню розробки й обґрунтування режимів рухової активності, піднята проблема залишається актуальною, що зумовлено необхідністю переосмислення режиму рухової активності студентів закладів вищої освіти з урахуванням особливостей навчання.

МЕТА І ЗАВДАННЯ ДОСЛІДЖЕНнЯ - визначити рівень рухової активності студентів педагогічних спеціальностей.

МЕТОДИ ДОсЛІДЖЕННЯ: фременгемська методика, методи статистичної обробки даних.

\section{РЕЗУЛЬТАТИ ДОСЛІДЖЕННЯ}

На сучасному етапі розвитку суспільства все гостріше постає проблема збереження і зміцнення здоров'я сучасної молоді, дотримання здорового способу життя. У нашій країні склалася критична ситуація із станом здоров'я населення. Різко зросла захворюваність, особливо на гіпертонію (у 3 рази), стенокардію (у 2,4 рази), інфаркт міокарда (на 30\%) (Блавт О. , 2012).

Дослідження свідчать, що систематичні заняття фізичними вправами, дотримання правильного рухового та гігієнічного режиму $€$ найефективнішими засобами запобігання багатьом захворюванням та підтримання нормального рівня працездатності організму (Куц А., 1993, с. 250).

Питання оптимальних рухових режимів, їхніх обсягів та інтенсивності добре вивчене стосовно методики підготовки спортсменів. Однак у методиці оздоровчих форм фізичної культури, у пошуку оптимальної і гранично припустимої інтенсивності навантаження для студентів педагогічних спеціальностей залишаються істотні проблеми. Рекомендації різних авторів цієї теми здебільшого суперечливі й дискусійні.

Практичний досвід показує, що студенти педагогічних спеціальностей не мають змоги повною мірою організовувати свою рухову активність. Це зумовлено досить великим розумовим навантаженням, низькою мотивацією до занять фізичною культурою, дотримання здорового способу життя й недостатньою ефективністю сучасної організації фізичного виховання студентів.

За даними Ю. П. Ядвіги, Г. В. Коробейнікова, Г. С. Петрова, зниження обсягу рухової активності студентів негативно позначається на їх фізичному розвитку, фізичній підготовці та функціональному стані, що зумовлює особливу соціальну значущість збереження і зміцнення здоров'я студентської молоді (Ядвіга Ю., 2009).

Нормою рухової активності студентів закладів вищої освіти можна вважати таку величину, котра повністю задовольняє біологічні потреби у рухах, відповідає функціональним можливостям організму, сприяє його розвитку, фізичній підготовленості та збереженню здоров'я. У науковій літературі та програмах з фізичного виховання оптимальний обсяг рухової активності студентів становить 12-14 годин на тиждень при достатньому фізіологічному навантаженні (Футорный С., 2013).

Для визначення рухової активності студентів педагогічних спеціальностей нами було використано Фремінгемську методику, де рухова активність досліджується в такий спосіб: кожен випробуваний записує в таблицю ту кількість годин у день, що він затратив на діяльність різного рівня фізичної активності. Фремінгемська методика дозволяє кількісно і якісно визначати добову рухову активність на основі хронометражу добової діяльності різного характеру з реєстрацією інтенсивності кожного виду фізичних зусиль. Величина цих вимірів представляється у вигляді цифрового значення індексу фізичної активності. При хронометражі реєструється вся діяльність, якою займається досліджуваний, що розподіляється на п'ять рівнів: базовий, сидячий, малий, помірний, інтенсивний (табл.1). 


\section{Показники фізичного стану хлопців та дівчат I курсу педагогічних спеціальностей}

\begin{tabular}{|c|l|c|c|c|c|}
\hline \multirow{2}{*}{$\begin{array}{c}\text { № } \\
\text { пп }\end{array}$} & \multirow{2}{*}{$\begin{array}{c}\text { Рівні рухової } \\
\text { активності }\end{array}$} & \multicolumn{2}{|c|}{ Хлопці } & \multicolumn{2}{c|}{ Дівчата } \\
\cline { 3 - 6 } & ІФА & $\%$ & ІФА & $\%$ \\
\hline 1 & Базовий & 7,6 & 31,9 & 8,0 & 33,4 \\
\hline 2 & Сидячий & 3,7 & 15,7 & 3,8 & 16,1 \\
\hline 3 & Малий & 8,7 & 36,5 & 9,4 & 39,2 \\
\hline 4 & Середній & 3,4 & 14,1 & 2,7 & 11,5 \\
\hline 5 & Високий & 1,3 & 5,6 & 0,8 & 3,4 \\
\hline
\end{tabular}

На базовому рівні, до якого належать сон, відпочинок лежачи, рівень рухової активності в юнаків становив 7,6 год, а в дівчат - 8,0 год, Пересування в транспорті, читання, малювання, перегляд телепередач, настільні та комп'ютерні ігри, споживання їжі - види діяльності, які належать до сидячого рівня рухової активності, на який студенти в середньому витрачають 3,7 год та 3,8 год відповідно.

Середня тривалість малого рівня добової рухової активності (особиста гігієна, пересування пішки, заняття у 3ВО, окрім фізичної культури) у хлопців становила в середньому 8,7 год, у дівчат 9,4 год. Аналіз хронометражу добової рухової активності студентів показав, що більшу частину займає малий рівень рухової активності: 8,7 годин у хлопців та 9,4 години у дівчат.

Зареєстровані показники середнього й високого рівнів рухової активності були найменші. Так, середній рівень рухової активності, до якого належать домашня робота по господарству, прогулянки, ранкова гімнастика, становив 3,4 години у юнаків і 2,7 години у дівчат.

У процентному співвідношенні ці рівні становили: базовий - 31,9 \%, сидячий - 15,7 \%, малий - 36,5 \% добового бюджету часу в юнаків та 33,4 \%, 16,1 \% і 39,2 \% відповідно добового бюджету часу в дівчат.

Отже, близько 84,1\% добової рухової активності в студентів припадає на базовий, сидячий та малий рівні.

До високого рівня рухової активності відносили спеціально організовані заняття фізичними вправами й спортом, інтенсивні рухливі та спортивні ігри. На нього майбутні педагоги в середньому витрачають від 1,3 до 0,8 год., що становить 5,6\% та 3,4\% відповідно добової рухової активності.

Кількісна оцінка добового бюджету часу студентів показала, що 67,8 \% від загального обсягу добової рухової активності становила звична рухова активність, тобто всі види рухів, спрямовані на задоволення природних потреб людини, а також навчальна та виробнича діяльність.

Так, на навчальну діяльність студенти витрачають у середньому 29,5 \% часу доби. у структурі вільного часу пасивні види відпочинку (відпочинок сидячи, лежачи, сон) займають близько 38,3\% добових витрат часу. Спеціально організована м'язова діяльність становила лише 3,3 \% загального обсягу рухової активності.

Структура добової рухової активності студентів свідчить про переважання серед інших сидячого та малого рівнів активності. Так, у середньому на навчання дівчата витрачають 4,5 год., а хлопці - 3,8 години, 2,5 год у дівчат та хлопців витрачається на переїзд транспортом та вживання їжі, підготовка до занять займає 2,5 год у дівчат і 2,3 год у юнаків, відпочинок лежачи, відпочинок сидячи, прогулянки - близько 5,4 год на добу в дівчат та 4,9 год у юнаків.

Спеціально організована рухова активність у дівчат та хлопців становить 0,8 год та 1,3 год відповідно. Результати свідчать у більшості випадків про нераціональну організацію вільного часу студентської молоді.

Отже, отримані результати дослідження підтверджують думку про нераціональний режим дня в студентів закладів вищої освіти, доводять необхідність його корекції через включення заходів, що сприяють підвищенню спеціально організованої рухової активності й зокрема діяльності, що відповідає ї̈ високому рівню. Отримані результати доводять важливість потреби підвищення мотивації студентів до збільшення їхньої рухової активності.

\section{ВИСНОВКИ ТА ПЕРСПЕКТИВИ ПОДАЛЬШИХ ДОСЛІДЖЕНЬ}

Результати дослідження свідчать про низький рівень рухової активності студентів І курсу. Так, обсяг рухової активності у дівчат та хлопців становить 0,8 год та 1,3 год відповідно. Виходячи із вищесказаного, належним чином організована рухова активність і оптимальні фізичні навантаження здатні безпосередньо впливати на збереження і підвищення не тільки фізичної підготовки, але й розумової працездатності. Впровадження програм фізкультурно-оздоровчих занять, побудованих на стимулюванні мотивації до систематичних занять фізичними вправами, буде сприяти залученню студентів до рухової активності. Ці питання є досить важливими у вихованні й визначають етичне і духовне здоров'я суспільства, що потребує подальшого поглибленого вивчення.

\section{СПИСОК ВИКОРИСТАНИХ ДЖЕРЕЛ}

Анікєєв, Д. (2012). Рухова активність у способі життя студентської молоді (Автореферат дисертації кандидата наук з фізичного виховання і спорту). Нац. університет фізичного виховання і спорту України, Київ.

Блавт, О. (2012). Інформативні показники рівня фізичного здоров'я та фізичної підготовленості студентів ВНЗ. Педагогіка, психологія та медико-біологічні проблеми фізичного виховання і спорту. Харків, 14-18. 
Куц, А. (1993). Модельные показатели физического развития и двигательной подготовленности населения центральной Украины: Монография. Киев.

Ніколаєв, С. (2004). Оптимізація рухової активності студенток залежно від психофізичних особливостей (Автореферат дисертації кандидата наук з фізичного виховання і спорту). Луцьк.

Сікура, А. (2012). Гіпокінезія як різновид залежності. Фізичне виховання, спорт і культура здоров'я у сучасному суспільстві. Волинський національний університет імені Лесі Українки. Луцьк, 247-252.

Футорный, С. (2013). Проблема дефицита двигательной активности студенческой молодежи. Физическое воспитание студентов. №3, 75-79.

Ядвіга, Ю. (2009). Вплив рухової активності на психоемоційний стан студентів ВНЗУ економічних спеціальностей в сучасних умовах навчання. Педагогіка, психологія та медико-біологічні проблеми фізичного виховання і спорту : зб. наук. праць. Харків, 12, 202-204.

\section{REFERENCES}

Anikieiev, D. (2012). Rukhova aktyvnist u sposobi zhyttia studentskoi molodi. (Avtoreferat dysertatsii kandydata nauk z fiz. vykhovannia i sportu). Nats. universytet fizychnoho vykhovannia i sportu Ukrainy, Kyiv.

Blavt, O. (2012). Informatyvni pokaznyky rivnia fizychnoho zdorovia ta fizychnoi pidhotovlenosti studentiv VNZ. Pedahohika, psykholohiia ta medykobiolohichni problemy fizychnoho vykhovannia i sportu. Kharkiv, 14-18.

Kuts, A. (1993). Modelnye pokazateli fizicheskogo razvitiya i dvigatelnoy podgotovlennosti naseleniya tsentralnoy Ukrainy: Monografiya. Kyev.

Nikolaiev, S. (2004). Optymizatsiia rukhovoi aktyvnosti studentok zalezhno vid psykhofizychnykh osoblyvostei. (Avtoreferat dysertatsii kandydata nauk z fiz. vykhovannia i sportu). Lutsk.

Sikura, A. (2012). Hipokineziia yak riznovyd zalezhnosti. Fizychne vykhovannia, sport i kultura zdorovia u suchasnomu suspilstvi : zb. nauk. pr. Volyn.nats. un-tu im. Lesi Ukrainky. Lutsk, 247-252.

Futornyiy, S. (2013). Problema defitsita dvigatelnoy aktivnosti studencheskoy molodezhi. Fizicheskoe vospitanie studentov. 3, 75-79.

Yadviha, Yu. (2009). Vplyv rukhovoi aktyvnosti na psykhoemotsiinyi stan studentiv VNZU ekonomichnykh spetsialnostei v suchasnykh umovakh navchannia. Pedahohika, psykholohiia ta medyko-biol. problemy fizychnoho vykhovannia i sportu: zb. nauk. prats. Kharkiv, 12, $202-204$.

Статтю подано до редколеаії 25.09.2019 p.

Рекомендовано до друку $\quad$ 09.10.2019 p. 